\title{
Pengaruh Keterlibatan Orang Tua dan Motivasi Intrinsik dengan Kepercayaan Diri Anak Usia Dini
}

\author{
Rachma Dwi Ardiyana ${ }^{1 凶}$, Zarina Akbar ${ }^{2}$, Karnadi $^{3}$ \\ Pendidikan Anak Usia Dini, Universitas Negeri Jakarta
}

\begin{abstract}
Abstrak
Penelitian ini bertujuan untuk mengetahui pengaruh antara keterlibatan orang tua dan motivasi intrinsik dengan kepercayaan diri. Metode yang digunakan adalah survei dengan studi korelasional dengan melibatkan 100 orang sampel. Ada tiga instrumen yang mengukur keperayaan diri anak (rel..875), keterlibatan orang tua (rel .962), dan motivasi intrinsik (rel .82). Data telah dianalisis oleh ANOVA dua arah. Hasil penelitian mengungkapkan bahwa ada korelasi positif dan signifikan antara variabel-variabel tersebut, meskipun sudah dikontrol oleh korelasi orde kedua, masih signifikan di antara mereka. Karena itu dapat disimpulkan bahwa jika kepercayaan diri anak akan ditingkatkan, maka keterlibatan orang tua dan motivasi intrinsik harus dipertimbangkan.
\end{abstract}

Kata Kunci: keterlibatan orang tua; motivasi intrinsik; kepercayaan diri anak

\begin{abstract}
This study aims to determine the effect of parental involvement and intrinsic motivation and self-confidence. The method used is a survey with a correlational study involving 100 sample people. There are three instruments that measure children's self-esteem (rail .875), parental involvement (rel. 962), and intrinsic motivation (rel .82). Data has been analyzed by two-way ANOVA. The results revealed that there were positive and significant correlations between these variables, even though they were controlled by second-order correlations, still significant between them. Therefore it can be concluded that if a child's self-confidence is to be improved, parental involveament and intrinsic motivation must be considered.
\end{abstract}

Keywords: parent involvement; intrinsic motivation; and child confidence

Copyright (c) 2019 Rachma Dwi Ardiyana, Zarina Akbar, Karnadi

$\triangle$ Corresponding author :

Address : De'Sanctuary D/28 Bekasi

ISSN 2356-1327 (Media Cetak)

Email : rd.ardiyana@gmail.com

ISSN 2549-8959 (Media Online) 


\section{PENDAHULUAN}

Kepercayaan diri adalah satu aspek kepribadian yang penting pada seseorang. Tanpa kepercayaan diri akan banyak menimbulkan masalah pada diri seseorang. Keperayaan diri merupakan atribut yang paling berharga pada diri seseorang dalam kehidupan bermasyarakat. Dikarenakan dengan kepercayaan diri seseorang mampu mengaktualisasikan segala potensi dirinya. Kepercayaan diri diperlukan baik oleh seorang anak ataupun orangtua, secara individual maupun kelompok.

Warren (2010) Kepercayaan diri merupakan keyakinan diri akan kemampuan sendiri menghadapi tantangan ketika menghadapi masalah. Dengan kepercayaan diri, anak mampu mengatasi tantangan yang baru, meyakini diri sendiri dalam keadaan sulit, dan mampu mengembangkan sikap positif tanpa mengawatirkan berbagai situasi dan kondisi. Kepercayaan diri oleh Navaja \& Geetha (2007) dipandang sebagai salah satu aspek penting dalam pembentukan kepribadian anak.

Bejalan dengan penelitian Karimi \& Saadatmand, (2016) mengatakan kepercayaan diri anak memberi kekuatan yang dapat mempengaruhi pada penilaian kemampuan anak dan kesediaan untuk mengerjakan tugas. Anak yang kurang percaya diri akan menjadi seseorang yang pesimis dalam menghadapi tantangan, takut dan ragu ragu untuk menyampaikan gagasan, serta bimbang dalam menentukan pilihan dan sering membanding bandingkan dirinya dengan orang lain. Jadi kepercayaan diri memiliki peranan penting dalam kesuksesan dalam prestasi anak dalam belajar. Kepercayaan diri anak dapat mengeluarkan seluruh potensi yang dimilikinya.

Penelitian yang dilakukan oleh Charness, Rustichini, \& Ven (2017) mengatakan bahwa kepercayaan diri banyak terjadi ketika berada di lingkungan yang akrab. Apabila lingkungan terasa akrab, maka secara tidak sadar dapat menumbuhkan rasa kepercayaan diri yang tinggi. Oleh sebab itu, lingkungan sangat mempengaruhi pembentukan rasa percaya diri pada seseorang. Mengingat betapa pentingnya memiliki rasa kepercayaan diri,

Dalam penelitian Agusriani (2015) mengatakan bahwa bermain gerak dapat meningkatkan kemampuan motorik kasar dan kepercayaan diri anak. Sejalan dengan penelitian Hermayanti (2015) mengatakan bahwa kegiatan menari kreatif dapat meningkatkan kepercayaan diri anak. Dari hasil penelitian tersebut dapat diartikan bahwa kepercayaan diri dapat di stimulasi dengan berbagai kegiatan.

Pentingnya memiliki rasa kepercayaan diri, setiap tempat dan suasana perlu dibangun secara optimal dan positif. Bagi orangtua dan guru diharapkan dapat membantu perkembangan rasa percaya diri pada anak dan sama sama saling menyadari bahwa dengan dimilikinya rasa percaya diri yang positif pada anak akan membawa keuntungan diberbagai pihak. Masa depan anak sangat tergantung dari pengalaman yang didapat anak termasuk faktor pendidikan dan pola asuh orangtua.

Hasil penelitian yang dilakukan oleh Mohammadi (2017) menyatakan bahwa keluarga mempunyai peranan penting bagi anak. Keluarga yang memiliki keserasian atau kekompakan, dapat meningkatkan prestasi akademik dan kepercayaan diri anak. Hasil penelitian Rahminur Diadha mengatakan Keterlibatan orangtua merupakan aspek penting dalam sebuah pendidikan terutama dalam Pendidikan Anak Usia Dini (PAUD).

Menurut Morisson keterlibatan orangtua merupakan suatu proses dimana orangtua menggunakan segala kemampuan mereka guna keuntungan mereka sendiri, 
anak-anaknya, dan program yang dijalankan anak itu sendiri. Orangtua merupakan orang yang paling bertanggung jawab atas seorang anak, dari sejak lahir hingga anak tumbuh menjadi pribadi yang dewasa. Orangtua mempunyai kewajiban dalam memelihara dan menjaga keberlangsungan kehidupan anaknya. Orangtua merupakan pendidik pertama anak di rumah dan merupakan orang yang pertama kali berinteraksi dengan anak. Dalam proses pendidikan di rumah, untuk membantu anak dalam belajar banyak hal yang dapat dilakukan oleh orangtua antara lain, orangtua diharapkan dapat mengotrol, memberi petunjuk, memberi bimbingan, dan memberikan motivasi kepada anaknya

$$
\text { Menurut Sardiman }
$$

mengemukakan bahwa Motivasi Intrinsik adalah motif-motif yang menjadi aktif atau berfungsinya sehingga tidak perlu rangsangan dari luar, karena dari dalam diri individu sudah ada dorongan untuk melakukan sesuatu. Sedangkan motivasi Ekstrinsik adalah motif-motif yang aktif dan berfungsinya karena adanya perangsang dari luar. Belajar memerlukan motivasi. Motivasi merupakan suatu kekuatan yang dapat mendorong seseorang untuk melakukan suatu perbuatan, termasuk belajar. Motivasi untuk melakukan belajar adalah penting dalam melakukan kegiatan belajar dikarenakan motivasi intrinsik merupakan pendorong yang dapat melahirkan kegiatan seseorang. Seseorang akan lebih cenderung semangat untuk menyelesaikan suatu kegiatan karena ada motivasi yg kuat dari dalam dirinya sendiri. Motivasi sebagai suatu pendorong yang mengubah energy dalam diri seseorang kedalam bentuk suatu kegiatan nyata untuk mencapai tujuan tertentu. Dengan kata lain individu terdorong untuk bertingkah laku ke arah tujuan tertentu tanpa adanya faktor pendorong dari luar. Berdasarkan pendapat - pendapat tersebut diatas dapat dikatakan bahwa motivasi intrinsic tidak memerlukan rangsangan dari luar tetapi berasal dari diri sendiri.

$\begin{array}{crr}\text { Hasil penelitian dari } & \text { Mariela } \\ \text { Pavalache-Ilie } & \text { (2014) } & \text { menyatakan }\end{array}$ ketertarikan orangtua yang membantu pekerjaan anaknya di sekolah dan terlibat didalam lingkungan sekolah dengan menggunakan evaluasi interaksi guru dan persepsi guru tentang keterlibatan dengan orangtua hasilnya mengkonfirmasi hipotesis bahwa kinerja sekolah secara signifikan terkait dengan tingkat keterlibatan orangtua dan motivasi intrinsik.

Selanjutnya penelitian terkait dari Desi Mardiati, Aloysius Mering, Dian Miranda (2016) telah membuktikan bahwa ada hubungan yang signifikan antara kepercayaan diri dengan motivasi belajar pada anak kelompok B Dari hasil penelitian sebelumnya dapat dikatakan bahwa dengan keterlibatan orang dan motivasi instrinsik dapat mempengaruhi kepercayaan diri anak

Percaya diri merupakan modal dasar untuk pengembangan dalam aktualisasi diri (eksplorasi segala kemampuan dalam diri). Dengan percaya diri seseorang akan mampu mengenal dan memahami diri sendiri. Seseorang yang memiliki rasa percaya diri akan berusaha sekeras mungkin untuk mengeksplorasi semua bakat yang dimilikinya. Seseorang yang memiliki rasa percaya diri akan menyadari kemampuan yang ada pada dirinya, mengetahui dan menyadari bahwa dirinya memiliki bakat, keterampilan atau keahlian sehingga orang tersebut akan bertindak sesuai dengan kapasitas yang dimilikinya.

Menurut Hygiene Kepercayaan Diri adalah penilaian yang relatif tetap tentang diri sendiri, mengenai kemampuan, bakat, kepemimpinan, inisiatif, dan sifat-sifat lain, serta kondisi-kondisi yang mewarnai perasaan manusia (Iswidharmanjaya \& Enterprise, 2014:20-21). Orang yang percaya diri lebih mampu dalam 
menyesuaikan diri dengan lingkungan yang baru, orang yang percaya diri biasanya akan lebih mudah berbaur dan beradaptasi dibanding dengan yang tidak percaya diri. Karena orang yang percaya diri memiliki pegangan yang kuat, mampu mengembangkan motivasi, ia juga sanggup belajar dan bekerja keras untuk kemajuan, serta penuh keyakinan terhadap peran yang dijalaninya, sejalan dengan pendapat santrock Rasa percaya diri juga disebut sebagai harga diri atau gambaran diri, merupakan dimensi evaluatif yang menyeluruh dari diri. Percaya diri adalah kondisi mental atau psikologis seseorang, dimana individu dapat mengevaluasi keseluruhan dari dirinya sehingga memberi keyakinan kuat pada kemampuan dirinya untuk melakukan tindakan dalam mencapai berbagai tujuan didalam hidupnya (Setiawan, 2014:14). Untuk itu kepercayaan merupakan keyakinan dalam diri seseorang bilamana ia mampu mencapai kesuksesan dengan berpijak pada usahanya sendiri

Kepercayaan diri terdiri atas beberapa aspek. Menurut Lauster (2002), aspekaspek kepercayaan diri meliputi: 1 . Optimis, merupakan sikap positif seseorang yang selalu berpandangan baik dalam menghadapi segala hal tentang diri, harapan dan kemampuan. 2. Keyakinan pada kemampuan sendiri, merupakan sikap positif seseorang yang mengerti dengan sungguh-sungguh akan apa yang dilakukannya. 3. Toleransi, adalah sikap menghargai, menenggang, tidak mau capur tangan serta membiarkan tindakan, sikap dan pendapat orang lain. 4. Ambisi normal, adalah suatu keadaan seseorang yang memiliki keinginan untuk mencapai segala sesuatu yang dicita-citakan. 5. Tanggung jawab, merupakan kesediaan seseorang untuk menanggung segala sesuatu yang telah menjadi konsekuensinya. 6. Rasa aman, adalah keadaan seseorang yang merasa tidak takut dan khawatir mengenai

Pemuasan kebutuhannya dikemudian hari dan mampu menghadapi segala sesuatu dengan tenang. 7. Mandiri, adalah sikap positif seseorang untuk tidak bergantung pada orang lain. 8. Mudah menyesuaikan diri, merupakan sikap positif yang dimiliki oleh seseorang untukmelakukan interaksi dengan lingkungan sekitarnya sehingga merasa sesuai dan cocok dengan lingkungan tersebut.

Lauster (2002) menambahkan bahwa orang yang percaya diri memiliki sikap peduli dengan orang atau toleransi, mandiri, dan menjadi diri sendiri. Orang yang percaya diri bukan berarti hanya memahami dirinya sendiri sehingga mengabaikan orang lain melainkan menghargai dan peduli terhadap orang lain. Salah satu faktor yang mempengaruhi adalah orang tua, Orang tua merupakan kontak sosial yang paling awal yang dialami oleh seseorang dan yang paling kuat, maka tak jarang orang tua dan anak bagaiman dua orang yang sama-sama memiliki rasa dan telepati tinggi. Informasi yang diberikan orang tua kepada anaknya lebih dipercaya dari pada informasi yang diberikan oleh orang lain dan berlangsung hingga dewasa.

Motivasi memiliki peran penting dalam proses pembelajaran untuk mendapatkan hasil akademik yang lebih baik (Singh, 2011:36), dikarenakan dengan adanya motivasi ini seseorang akan memiliki energi untuk bergerak, dan mampu mempertahankannya untuk mendapatkan hasil yang maksimal.

Motivasi memiliki peran penting dalam proses pembelajaran untuk mendapatkan hasil akademik yang lebih baik (Singh, 2011:36), dikarenakan dengan adanya motivasi ini seseorang akan memiliki energi untuk bergerak, dan mampu mempertahankannya untuk mendapatkan hasil yang maksimal. 
Seseorang yang memiliki motivasi umumnya akan mampu menyelesaikan tujuan yang ingin dicapainya walaupun di dalam perjalanan mendapatkan tujuan tersebut, dia akan menghadapi rintangan yang tidak sedikit. Oleh karena itu, banyak ahli yang kemudian menyimpulkan bahwa motivasi sangat erat kaitannya dengan perilaku, bahkan menurut teori pembelajaran perilaku konsep motivasi berkaitan erat dengan prinsip bahwa perilaku yang telah dikuatkan pada masa lalu lebih mungkin diulangi daripada perilaku yang belum dikuatkan atau yang telah dihukum (Slavin, 2011).

Motivasi sendiri kemudian didefinisikan sebagai proses internal yang mengaktifkan, menuntun, dan mempertahankan perilaku dari waktu ke waktu (Pintrich, 2003 dalam Slavin, 2011). Hal ini senada dengan kesimpulan yang dikemukakan oleh Ahmed, F., Miller, L. (2011), yang mendefinisikan motivasi sebagai kondisi internal yang menstimulasi, menggerakkan, dan memelihara perilaku, sedangkan Singh (2011) menyebutkan motivasi sebagai penggerak untuk mencapai target dan proses untuk memelihara penggerak tersebut. Dengan bahasa sederhana, motivasi adalah sesuatu yang menyebabkan seseorang melangkah, membuatnya tetap melangkah, dan menentukan ke mana seseorang tersebut mencoba melangkah (Slavin, 2011). Sejalan dengan Purwanto (2014) mendefinisikan motivasi sebagai suatu usaha yang disadari untuk menggerakkan, mengarahkan, dan menjaga tingkah laku seseorang agar ia terdorong untuk bertindak melakukan sesuatu sehingga mencapai hasil atau tujuan tertentu. Sedangkan Schunk, Pintrich \& Meece (2012)

Menurut Ormrod (2002) ada 2 jenis motivasi yaitu 1. Motivasi intrinsik , Motivasi intrinsik adalah motivasi yang disebabkan oleh faktor dalam dirinya. Anak yang termotivasi secara intrinsik akan merasa senang bila terlibat dalam suatu aktivitas yang dilakukan. 2. Motivasi ekstrinsik adalah motivasi yang disebabkan oleh faktor luar dirinya. Anak yang termotivasi secara ekstrinsik melakukan suatu aktivitas hanya sebagai sarana untuk mencapai tujuan, bukan sebagai tujuan untuk dirinya sendiri (Eriany, Hernawati, Goeritno, 2014:119

Lebih lanjut dijelaskan Menurut Sardiman (2014:89) mengemukakan bahwa Motivasi Intrinsik adalah motif-motif yang menjadi aktif atau berfungsinya sehingga tidak perlu rangsangan dari luar, karena dari dalam diri individu sudah ada dorongan untuk melakukan sesuatu. Di dalam penelitian oleh Mariela PavaLache, FeliciaAntonia Tirdia (2014) dengan judul “ Patental Involvement And Intrinsic Motivation With Primary School Students. Hasilnya mengkonfirmasi hipotesis bahwa kinerja sekolah secara signifikan terkait dengan tingkat keterlibatan orang tua dan intrinsik.

Para peneliti sering kontras intrinsik motivasi dengan motivasi ekstrinsik, yang motivasi diatur oleh penguatan kontinjensi. Secara tradisional, pendidik mempertimbangkan motivasi intrinsik untuk menjadi lebih diinginkan dan untuk menghasilkan hasil belajar yang lebih baik daripada motivasi ekstrinsik. Berdasarkan pendapat para ahli di atas maka disintesiskan bahwa percaya diri (Self confidence) adalah sejauh mana keyakinan terhadap penilaian atas kemampuan untuk berhasil, kepercayaan diri meliputi beberapa aspek yaitu 1. Pandangan Positif terhadap diri sendiri yaitu percaya akan kemampuan diri dan dapat berinteraksi dengan orang lain. 2. Keberanian yaitu berani mengemukakan pendapat dan tindakan, berani dalam bertindak dan berani berkomunikasi. 3. Optimis yaitu sikap positif anak yang selalu berpandangan baik 
dalam menghadapi segala hal tentang diri, harapan dan kemampuannya.

Keterlibatan orang tua dalam proses pembelajaran anak usia dini memiliki alasan sebagai berikut; 1) Keinginan orangtua untuk terlibat, keinginan orang tua yang ingin terlibat secara penuh telah meningkat dari tahun ke tahun; 2) Peningkatan Prestasi dan Keterampilan Sosial, ketika orang tua terlibat citra diri dan prestasi anak-anak meningkatkan; 3) Dukungan orang tua, orang tua lebih mendukung program di mana mereka memiliki kontak langsung dan keterlibatan bermakna; 3) Hak Orang tua, pendidik anak usia dini mengakui bahwa orang tua memiliki hak untuk terlibat dalam programprogram yang mempengaruhi mereka; 4) Tugas orangtua, setiap orang tua harus terlibat dalam beberapa cara untuk setidaknya ketika anak-anak mereka dalam program (Morrison, 2008: 320). Program keterlibatan orang tua dapat diterapkan untuk berbagai model pembelajaran anak usia dini, itu karena prinsip-prinsip yang dikembangkan dalam program anak usia dini tidak bias terlepas dari campur tangan orang tua sebagai individu yang paling dekat dengan anak.

Melibatkan orang tua dalam program pendidikan juga tidak bisa dilepaskan dengan kesiapan sekolah atau program itu sendiri. Menurut Morrison (2008: 323), tingkat kesiapan sekolah atau program terbagi sebagai berikut, 1) Level 1, keterlibatan orangtua dalam pada level ini mempengaruhi kesiapan pendidik dalam bersikap dan mengembangkan kemampuan,

2) Level 2, kesiapan orangtua yang berhubungan dengan kesiapan program. Dengan pengertian bahwa keterlibatan orangtua merupakan proses yang berkembang, sehingga setiap tingkatan kesiapan baik orangtua maupun sekolah dapat terus melakukan perbaikan agar keduanya memiliki kesamaan.
Salah satu faktor yang berpengaruh terhadap hasil belajar siswa adalah keterlibatan orang tua. Keterlibatan orang tua mencerminkan sejauh mana orang tua hadir dan menyisipkan diri mereka ke dalam kehidupan anak-anaknya (Gonzalez \& Wolters, 2006). Keterlibatan orangtua juga termasuk komunikasi antara orang tua dan guru (Daniela POPA, 2016); partisipasi orang tua dalam kegiatan-kegiatan sekolah seperti pertemuan orang tua dengan guru (Milad Khajehpour, 2011); bantuan yang diberikan orang tua ketika anaknya mendapat Pekerjaan Rumah (PR) dari sekolah (Shumow dan Miller, 2011); serta perilaku orang tua di rumah dan di sekolah dengan tujuan untuk membantu pengalaman belajar anak (Bano Fakhra Batool, 2013). Keterlibatan orang tua memiliki peran penting dalam pencapaian pendidikan anak. Semakin peduli orang tua, akan semakin tinggi bantuan dan dukungan yang diberikan, dan semakin baik pencapaian keberhasilan pendidikan anak.

Penelitian yang telah dilakukan oleh Kim (2012), menemukan adanya hubungan yang signifikan antara keterlibatan orangtua dengan prestasi yang dicapai siswa di sekolah. Van Voorhis (2013) mengemukakan bahwa siswa akan memperoleh capaian akademik yang lebih tinggi ketika orang tua memberikan bantuan dalam pengerjaan tugas-tugas di rumah. Hal yang sama diungkapkan oleh lisa bonk, dkk., (2018) bahwa bantuan orang tua yang diberikan ketika siswa akan mengambil keputusan berhubungan dengan capaian siswa di bidang akademik. Akan tetapi, dalam beberapa penelitian lainnya ditemukan bahwa tidak terdapat bukti signifikan bahwa keterlibatan orang tua berpengaruh langsung terhadap hasil belajar siswa (Bobbett et al., 2005) dan bahkan terdapat hubungan negatif di antara dua variabel tersebut. 
$500 \mid$ Pengaruh Keterlibatan Orang Tua dan Motivasi Intrinsik dengan Kepercayaan Diri

keterlibatan orangtua dengan prestasi yang dicapai siswa di sekolah. Van Voorhis (2013) mengemukakan bahwa siswa akan memperoleh capaian akademik yang lebih tinggi ketika orang tua memberikan bantuan dalam pengerjaan tugas-tugas di rumah. Hal yang sama diungkapkan oleh Lamborn et al., (2012) bahwa bantuan orang tua yang diberikan ketika siswa akan mengambil keputusan berhubungan dengan capaian siswa di bidang akademik. Akan tetapi, dalam beberapa penelitian lainnya ditemukan bahwa tidak terdapat bukti signifikan bahwa keterlibatan orang tua berpengaruh langsung terhadap hasil belajar siswa (Bobbett et al., 2005) dan bahkan terdapat hubungan negatif di antara dua variabel tersebut.

Tidak adanya konsistensi hasil temuan-temuan tersebut disinyalir merupakan hasil dari adanya pengaruh tidak langsung keterlibatan orang tua terhadap hasil belajar siswa (El-Fattah, 2016). Tidak ditemukannya bukti pengaruh langsung keterlibatan orang tua terhadap hasil belajar siswa mungkin disebabkan oleh adanya variabel lain yang menjadi mediasi atau perantara di antara dua variabel tersebut (Keith et al.,2006).

Berdasarkan pemaparan diatas, maka disintesiskan Keterlibatan orang tua adalah partisipasi orang tua dalam kegiatan di sekolah dan rumah. Meliputi membantu pekerjaan anak di sekolah, teribat dalam kegiatan di sekolah. Keterlibatan orang tua serta pengalaman dalam mendidik dan membimbing anak. keterlibatan orang tua merupakan perilaku dari orang tua dalam proses belajar anak yang terbagi menjadi beberapa level, yaitu Dukungan (Encouragement), Percontohan (Modeling). Penguatan (Reinforcement) dan Pengajaran (Instruction)

\section{METODOLOGI}

Metode penelitian yang dipergunakan adalah metode survey, yaitu metode penelitian yang digunakan untuk mengungkap hubungan antara variabel keterlibatan orang tua, motivasi intrinsik dan kepercayaan diri. Populasi dalam penelitian ini, dibedakan menjadi dua kelompok yaitu populasi target dan populasi terukur. Populasi target dalam penelitian ini adalah orang tua yang memiliki anak duduk di bangku kelas 3 SD Kelurahan Jatibening, kecaman Pondokgede, Kota Bekasi. Pengambilan sampel ini dilakukan dengan cara purposive sampling di Kelurahan Jatibening yaitu teknik sampling non random sampling Metode korelasional dengan konstelasi masalahnya sebagai berikut:

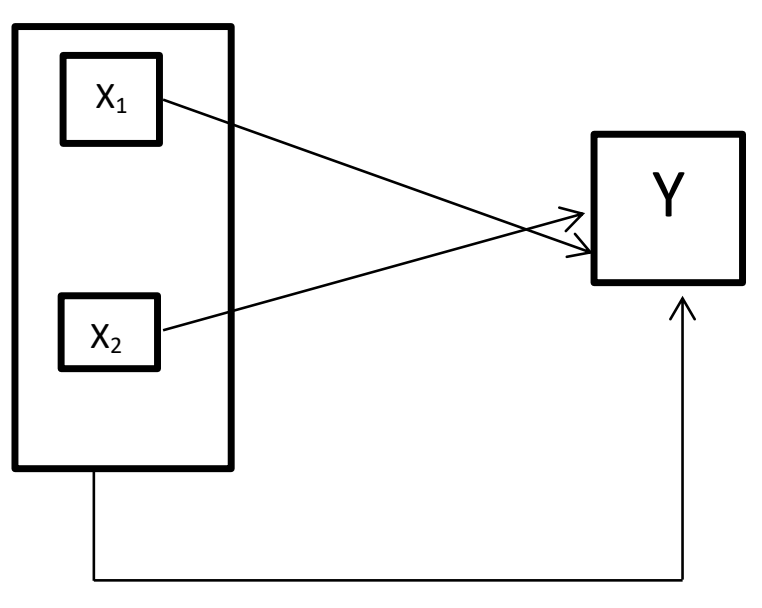

Gambar 3.1 Konstelasi masalah

Keterangan :

$\mathrm{Y}=$ Variabel terikat: Kepercayaan Diri Anak

$\mathrm{X}_{1}=$ Variabel bebas $1:$ Keterlibatan Orang Tua $\mathrm{X}_{2}=$ Variabel bebas $2:$ Motivasi Intrinsik

Konstelasi tersebut menginformasikan bahwa ada hubungan simultan antara variabel keterlibatan orang tua dan Motivasi Intrinsik dengan motivasi Kepercayaan Diri Anak, terdapat hubungan yang simultan antara keterlibatan orang tua dengan Kepercayaan Diri Anak dan ada hubungan simultan antara Motivasi Intrinsik dengan Kepercayaan Diri Anak 
Responden dalam penelitian ini sebanyak 105 orang) dari 105 responden dipilih sampel sebanyak 100 orang siswa secara Purpose sampling. (Emzir.2012:6364).

Adapun teknik pengumpulan data sebagai berikut: kepercayaan diri Kketerlibatan orang tua (X1), dan motivasi intrinsik (X2)

\section{HASIL DAN PEMBAHASAN Hipotesis 1}

Hubungan antara variabel keterlibatan orang tua dengan kepercayaan diri anak dilakukan analisis regresi linier. Hasil analisis regresi linier tersebut mendapatkan persamaan $\hat{\mathrm{Y}}=62,5+0,776 \mathrm{X}_{1}$. Untuk pengujian keberartian dan linearitas regresi digunakan tabel ANAVA sebagai berikut :

Tabel 1. Uji Keberartian dan Kelinieran Regresi $Y$ atas $X_{1}$

\begin{tabular}{ccccccc}
\hline Sumber Varians & Df & JK & RJK & $F_{\text {calculation }}$ & $\begin{array}{c}\mathrm{F}_{\text {tabel }} \\
(\alpha=0,05)\end{array}$ & $\begin{array}{c}\mathrm{F}_{\text {tabel }} \\
(\alpha=0,01)\end{array}$ \\
\hline Total & 99 & & & & \\
Regresi (a) & 1 & & & & \\
Regresi (b|a) & 1 & 2562,618 & 2562,618 & $110,632^{* *}$ & 3,949 & 6,932 \\
Residu & 98 & 2270,022 & 23,163 & & & \\
Tuna Cocok & 26 & 2890,156 & 111,160 & $2,177^{\text {ns }}$ & 2,211 & \\
Galat & 73 & 1942,484 & 26,609 & & & \\
\hline \multicolumn{7}{c}{ Ket* $* *$ Sangat Signifikan; ns = tidaksignifikan (linier) }
\end{tabular}

Ket: ** Sangat Signifikan; ns = tidaksignifikan (linier)

Berdasarkan daftar ANAVA untuk uji keberartian dan linearitas regresi terlihat harga $F_{\text {hitung }}$ sebesar 110,632 dan 2,177; apabila diambil taraf nyata $\alpha=0,05$ maka untuk menguji hipotesis nol (I) yaitu dari daftar distribusi $\mathrm{F}$ dengan dk pembilang 1 dan dk penyebut 98 diperoleh $\mathrm{F}_{\text {tabel }} \alpha=0,05$ sebesar 3,949; dan untuk menguji hipotesis nol (II) dengan dk pembilang $26 \mathrm{dan} \mathrm{dk}$ penyebut 73 diperoleh $F_{\text {tabel }} \alpha=0,05$ sebesar 2,211; dengan demikian hipotesis nol (I) ditolak karena $F_{\text {hitung }}>F_{\text {tabel }}$, sehingga dari segi ini regresi diperoleh adalah signifikan. Hipotresis nol (II) diterima karena $F_{\text {hitung }}<F_{\text {tabel }}$ sehingga dapat dikatakan bahwa regresi linier. Berdasarkan hasil perhitungan koefisien korelasi diperoleh $\rho_{\mathrm{y} 1}=0,728$ dengan $\mathbf{t}_{\text {hitung }}$ $10.518>\mathbf{t}_{\text {tabel }} 1,66(\alpha=0,05)$, karena $\mathbf{t}_{\text {hitung }}$ $>\mathbf{t}_{\text {tabel }}(\alpha=0,05)$, maka $\mathrm{H}_{0}$ ditolak, yang berarti bahwa terdapat hubungan positif antara keterlibatan orang tua $\left(\mathrm{X}_{1}\right)$ dengan motivasi berprestasi (Y). Dari perhitungan juga diperoleh koefisien determinasi = 0,530 .

Penelitian yang telah dilakukan oleh Sahrip (2017), menemukan adanya hubungan yang signifikan antara interaksi dalam keluarga berpengaruh langsung secara signifikan terhadap percaya diri. Sehingga hipotesis yang menyatakan bahwa interaksi dalam keluarga berpengaruh langsung positif terhadap percaya diri dapat diterima. keterlibatan orangtua dengan prestasi yang dicapai siswa di sekolah. Van Voorhis (2013) mengemukakan bahwa siswa akan memperoleh capaian akademik yang lebih tinggi ketika orang tua memberikan bantuan dalam pengerjaan tugas-tugas di rumah. Hal yang sama diungkapkan oleh Lamborn et al., (2012) bahwa bantuan orang tua yang diberikan ketika siswa akan mengambil keputusan berhubungan dengan capaian siswa di bidang akademik. Akan tetapi, dalam beberapa penelitian lainnya ditemukan bahwa tidak terdapat bukti signifikan 
bahwa keterlibatan orang tua berpengaruh langsung terhadap hasil belajar siswa (Bobbett et al., 2005) dan bahkan terdapat hubungan negatif di antara dua variabel tersebut.

Salah satu faktor yang berpengaruh terhadap hasil belajar siswa adalah keterlibatan orang tua. Keterlibatan orang tua mencerminkan sejauh mana orang tua hadir dan menyisipkan diri mereka ke dalam kehidupan anak-anaknya (Gonzalez \& Wolters, 2006). Keterlibatan orangtua juga termasuk komunikasi antara orang tua dan guru (Deslandes et al., 2007); partisipasi orang tua dalam kegiatankegiatan sekolah seperti pertemuan orang tua dengan guru (Miedel dan Reynolds, 2009); bantuan yang diberikan orang tua ketika anaknya mendapat Pekerjaan Rumah (PR) dari sekolah (Shumow dan Miller, 2011); serta perilaku orang tua di rumah dan di sekolah dengan tujuan untuk membantu pengalaman belajar anak
(Bronfenbrenner, 2006). Keterlibatan orang tua memiliki peran penting dalam pencapaian pendidikan anak. Semakin peduli orang tua, akan semakin tinggi bantuan dan dukungan yang diberikan, dan semakin baik pencapaian keberhasilan pendidikan anak. Sehingga dalam hasil dan pembahasan ini terdapat hubungan antara keterlibatan orang tua dengan Kepercayaan diri anak kelas 3 Sekolah Dasar di Kota Bekasi.

\section{Hipotesis kedua}

Hubungan antara variabel motivasi intrinsik dengan kepercayaan diri anak ini menggunakan analisis sederhana atau analisis dilakukan analisis regresi sederhana. Hasil analisis regresi sederhana tersebut mendapatkan persamaan $\hat{\mathrm{Y}}=$ $19,393+0,724 \mathrm{X}_{2}$. Untuk pengujian keberartian dan linearitas regresi digunakan tabel ANAVA sebagai berikut:

Tabel 2. Uji Keberartian dan Kelinieran Regresi $Y$ atas $X_{2}$

\begin{tabular}{ccccccc}
\hline Sumber Varians & Df & JK & RJK & $F_{\text {hitung }}$ & $\begin{array}{c}\mathrm{F}_{\text {tabel }} \\
(\alpha=0,05)\end{array}$ & $\begin{array}{c}\mathrm{F}_{\text {tabel }} \\
(\alpha=0,01)\end{array}$ \\
\hline Total & 99 & & & & \\
Regresi (a) & 1 & & & & & \\
Regresi (b|a) & 1 & 788,783 & 788,783 & $19,116^{* *}$ & 3,949 & 6,932 \\
Residu & 98 & 4043,857 & 41,264 & & & \\
Tuna Cocok & 13 & 1278,125 & 98,317 & $1,379^{\text {ns }}$ & 1,643 & \\
Galat & 86 & 3554,515 & 41,332 & & & \\
\hline \multicolumn{7}{c}{ Ket: $* *$ Sangat Signifikan; ns = tidaksignifikan (linier) } \\
\end{tabular}

Hasil persamaan regresi diperoleh $F_{\text {hitung }}$ sebesar 19,116 lebih besar dari $F_{\text {tabel }}$ sebesar 3,949 $(\alpha=0,05)$ dan 6,932 $(\alpha=$ $0,01)$, dengan demikian $\mathrm{H}_{0}$ ditolak dan $\mathrm{H}_{1}$ diterima yang berarti model persamaan regresi sederhana untuk $\mathrm{Y}$ atas $\mathrm{X}_{2}$ terbukti signifikan. Uji linieritas diperoleh nilai $F_{\text {hitung }}$ sebesar 1,379 lebih kecil dari

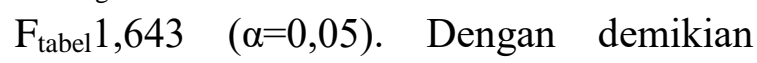
dapat dinyatakan bahwa model persamaan regresi sederhana untuk $\mathrm{Y}$ atas $\mathrm{X}_{2}$ terbukti linier. Berdasarkan hasil perhitungan koefisien korelasi diperoleh $\rho_{\mathrm{y} 2}=0,604$. Selanjutnya untuk mengetahui tingkat signifikansi koefisien korelasi, hasil uji menunjukkan $\mathbf{t}_{\text {hitung }} 14,372>\mathbf{t}_{\text {tabel }} 1,987(\alpha$ $=0,05)$, karena $\mathbf{t}_{\text {hitung }}>\mathbf{t}_{\text {tabel }}(\alpha=0,05)$, maka $\mathrm{H}_{0}$ ditolak, yang berarti bahwa terdapat hubungan positif antara persepsi tentang kecerdasan emosional $\left(\mathrm{X}_{2}\right)$ dengan motivasi berprestasi (Y). Dari perhitungan 
juga diperoleh koefisien determinasi = 0,365 .

Penelitian yang dilakukan oleh Noni Rozaini, Sandra Dwi Anti ( 2017) yang berjudul "Pengaruh Motivasi Belajar Dan Kepercayaan Diri Siswa Terhadap Prestasi Belajar" dalam penelitian ini menjelaskan permasalahan dalam penelian ini adalah apakah terdapat pengaruh motivasi belajar dan kepercayaan diri siswa terhadap prestasi belajar ekonomi siswa kelas XI SMA Swasta Raksana Medan Tahun Pelajaran 2015/2016. Berdasarkan hasil penelitian dapat disimpulkan bahwa motivasi belajar dan kepercayaan diri siswa berpengaruh terhadap prestasi belajar ekonomi siswa kelas XI IPS SMA Swasta Raksana Medan.

Dikatakan Dimyati dan Mudjiono (2002:97-100) bahwa terdapat beberapa hal yang mempengaruhi motivasi belajar siswa, antara lain : (a) adanya keinginan maju dalam belajar, (b) adanya kesadaran melakukan belajar, (c) adanya kegemaran belajar(d) adanya hasrat belajar. Berdasarkan teori dan hasil penelitian diatas peneliti menduga bahwa ada hubungan antara motivasi intrinsik dengan kepercayaan diri anak pada kelas 3 sekolah dasar di Kota Bekasi.

Penelitian yang dilakukan oleh Noni Rozaini, Sandra Dwi Anti ( 2017) yang berjudul "Pengaruh Motivasi Belajar Dan Kepercayaan Diri Siswa Terhadap Prestasi Belajar" dalam penelitian ini menjelaskan permasalahan dalam penelian ini adalah apakah terdapat pengaruh motivasi belajar dan kepercayaan diri siswa terhadap prestasi belajar ekonomi siswa kelas XI SMA Swasta Raksana Medan Tahun Pelajaran 2015/2016. Berdasarkan hasil penelitian dapat disimpulkan bahwa motivasi belajar dan kepercayaan diri siswa berpengaruh terhadap prestasi belajar ekonomi siswa kelas XI IPS SMA Swasta Raksana Medan.

Dalam kegiatan belajara mengajar di sekolah merupakan hal yang penting setidaknya para siswa memiliki motivasi untuk belajar karena kegiatan akan berhasil baik apabila anak yang bersangkutan mempunyai motivasi yang kuat. Slavin (2011) menyimpulkan bahwa motivasi sangat erat kaitannya dengan perilaku, bahkan menurut teori pembelajaran perilaku konsep, motivasi berkaitan erat dengan prinsip bahwa perilaku yang telah dikuatkan pada pengalaman yang didapat pada masa lalu dan kembali diulang. Sehingga terdapat hubungan antara motivasi intrinsic dengan kepercayaan diri anak kelas 3 SD kota Bekasi

\section{Hipotesi ketiga}

Terdapat hubungan antara keterlibatan orang tua dan motivasi intrinsic bersama sama dengan kepercayaan diri anak kelas 3 SD kota Bekasi. dilakukan analisis regresi sederhana. Hasil analisis regresi sederhana tersebut mendapatkan persamaan $\hat{\mathrm{Y}}=$ $13,827+0,720 \mathrm{X}_{1 .+} 0,492 \mathrm{X}_{2}$ Untuk pengujian keberartian dan linearitas regresi digunakan tabel ANAVA sebagai berikut :

Tabel 3. Uji Keberartian dan Kelinieran Regresi $Y$ atas $X_{1}, X_{2}$

\begin{tabular}{ccccccc}
\hline $\begin{array}{c}\text { Sumber } \\
\text { Varians }\end{array}$ & Dk & JK & RJK & $F_{\text {hitung }}$ & $\begin{array}{c}\mathrm{F}_{\text {tabel }} \\
(\alpha=0,05)\end{array}$ & $\begin{array}{c}\mathrm{F}_{\text {tabel }} \\
(\alpha=0,01)\end{array}$ \\
\hline Regresi & 2 & 2912,427 & 1456,214 & $73,561 * *$ & 3,949 & 6,932 \\
Residu & 97 & 1920,213 & & & & \\
Total & 99 & 4832,640 & 19,796 & & & \\
\hline
\end{tabular}

Ket: ** Sangat Signifikan; ns = tidaksignifikan (linier) 


\section{KESIMPULAN}

Berdasarkan hasil analisis yang sudah dijelaskan pada bagian terdahulu, maka selanjutnya dalam diuraikan berdasarkan temuan dari hasil penelitian. Hasil pengujian hipotesis menunjukkan bahwa: (1) Terdapat hubungan antara antara keterlibatan orangtua dengan Kepercayaan diri anak di kelas 3 Sekolah Dasar Kota Bekasi; (2) Terdapat hubungan antara motivasi intrinsik dengan Kepercayaan diri anak kelas 3 Sekolah Dasar Kota Bekasi; (3) Terdapat hubungan antara keterlibatan orangtua dan motivasi intrinsik secara bersama-sama dengan Kepercayaan diri anak di kelas 3 Sekolah Dasar Kota Bekasi.

\section{DAFTAR PUSTAKA}

A.M. Sardiman. 2010. Interaksi dan Motivasi Belajar Mengajar. Jakarta: Rajawali Pers.

Amini, M. (2015). Profil keterlibatan orang tua dalam pendidikan anak usia Tk. Jurnal Ilmiah Visi PPTK PAUDNI. 10( 1), 9- 20.

Arts and Social Sciences Journal:, Ubale AZ, Abdurrahman $\mathrm{T}$ and Abdullah AH (2015), "A Relationship between Parental Involvement and Intrinsic Motivation on Learning Islamic Education".

Carole Ames dan Madhab Khoju and Thomas Watkins (2013), "School/Family/Community partnersihps", kappanmagazine.org; hal.81

Dimyati dan Mudjiono. (1999). Belajar dan Pembelajaran. Jakarta : PT Rineka Cipta.

Ella Kurniawat, Muswardi Rosra, Diah Utaminingsih (2017)

Ghufron, Nur, dan Risnawita, Rini, teoriTeori Psikologi.(Jogjakarta;Ar-Ruzz Media.2011). Hal:33

Goleman, Daniel. 2006. Emotional Intelligence/Kecerdasan Emosiona Mengapa EI Lebih Penting Daripada IQ. Jakarta: PT Gramedia Pustaka Utama
Hamdu, Ghullam dan Lisa Agustina. 2011. "Pengaruh Motivasi Belajar Siswa Terhadap Pestasi Belajar Ipa Di Sekolah Dasar". Jurnal Penelitian Pendidikan, Vol. 12 No.1: 83.

Iswidharmanjaya, Derry dan Enterprise, Jubilee. 2014. Satu Hari Menjadi LebihPercaya Diri. Jakarta: Gramedia.

John G. Borkowski, Sharon Landesman Ramey, Maria Bristol -Power, '2002,'Parenting and the Child's World: Influeence on academi, intellectual, and soial-emotional development"

Jurnal Psikologi Canada oleh Maria A. Rogers, Jennifer Theule and Bruce A.Ryan, et all (2009) dalam Judulnya : "Parental Involment and Childrens School Achievement "

Lauster, P. (2003). Tes Kepribadian (alih bahasa: D.H. Gulo). Jakarta: PT. Bumi Aksara.

Longkutoy, dkk. (2015). Hubungan Pola Asuh Orang Tua dengan Kepercayaan Diri Siswa SMP Kristen Ranotongkor Kabupaten Minahasa. Diunduh pada tanggal 25 Juni 2016 dari ejournal.unsrat.ac.id

Mariela PavaLache, Felicia-Antonia Tirdia (2014) dengan judul “ Patental Involvement And Intrinsic Motivation With Primary School Students “

Midori Otani (2017), "Relationships between Parental Involvement and Academic Achievement among Elementary and Middle School Students", Osaka School of International Public Policy, Osaka University, 1-31 Machikaneyama, Toyonaka, Osaka 560-0043, JAPAN.

Modassir, Atika \& Singh, Tripti. 2008. "Relationship of Emotional Intelligence with Transformational Leadership and Organizational Citizenship Behavior". International Journal of Leadership Studies, Vol. 4 Iss. 1, 2008, pp. 3-21

Mohammadi, Azam dan Davarabina, Mehran. (2015). The effect cooperative learning techniques on reading comprehension ability of 
Iranian EFL learners. Internarional $\mathbf{J}$. soc. Sci \& Education, 5(3), 223-934, ISSN: 22234934

Noni Rozaini, Sandra Dwi Anti ( 2017) yang berjudul Pengaruh Motivasi Belajar Dan Kepercayaan Diri Siswa Terhadap Prestasi Belajar

Padavick, J.F. (2009). Parental involvement with learning and increased student achievement. Education Proquest Dissertations and Theses.

Parsons, R. D., Hinson, S. L., \& SardoBrown, D. (2001). Educational psychology: Apractitioner, researcher model of teaching. Singapore: Thomson Learning.

Porter, L. (Amini, M. (2014). Parental involvement for early childhood education in kinder garden. Dalam Adriani, V. (ed). Proceeding of International Conference of Early Childhood Education (ICECE) 1 (hlm. 172-177). Bandung: Prodi PG PAUD, FIP Universitas Pendidikan Indonesia.

Rizka Ayu Meidiastuti, Kriswandani, Inawati Budiono (2014) , motivasi belajar dan kepercayaan diri siswa terhadap pelajaran matematika masih kurang dan hasil belajar siswa masih rendah.

Santrock, John W., (2008). Psikologi Pendidikan, Edisi Kedua. Jakarta: Kencana.

Schunk, D.H., Pintrich, P.R., \& Meece, J.L., (2010). Motivation in Education: Theory, Research, and Applications Third Edition. New Jersey: Pearson Education.

Schunk, Daleh H., (2012). Teori-teori Pembelajaran: Perspektif Pendidikan. Yogyakarta: Pustaka Pelajar.

Setiawan, Pongky. 2014. Siapa Takut Tampil Percaya Diri?. Yogyakarta: Parasmu.

Siti Bariroh (2018)," The Influence of Parents' Involvement on Children with Special Needs' Motivation and Learning Achievement".

Slavin, R.E. (2009). Educational Psychology; Theory and Practice. (9th ed). Merrill/Pearson (2011).
Psikologi Pendidikan,Teori dan Praktik. (Terj. Samosir,M). Edisi Kesembilan. Jakarta: Indeks.

Slavin, Robert E., (2011). Psikologi Pendidikan Teori Dan Praktek Edisi Kesembilan Jilid 1, Jakarta: PT. Indeks.

Sugiyiono,2014. Metode peneitian Kuantitatif kualitatid dan R\&D. Bandung: CV Alfabeta

Sugiyono, Yuliani. 2011, "Konsep dasar pendidikan anak usia dini. Jakarta: PT.Indeks

Undang-Undang Republik Indonesia, No. 20, Tahun 2003, Tentang sistem pendidikan nasional.

Vanaja, Y., \& Geetha, D. (2017). A study on locus of control and self confidence high school students. Internasional Journal of Research Granthaalayah, ISSN 2350-0530(O); ISSN 2394-3629(P), 5(7).

White \& Coleman. (2000). Early childhood education: Building a philosophy for teaching. New Jersey: Prentice-Hall. Inc 